\title{
Navigating Terrorist Maneuvers in the Grid of COVID-19 Communities
}

\author{
Francis M. Kabosha \\ Independent Scholar, Zambia \\ Email:fmkabosha@yahoo.co.uk
}

How to cite this paper: Kabosha, F.M. (2021) Navigating Terrorist Maneuvers in the Grid of COVID-19 Communities. Open Access Library Journal, 8: e6792. https://doi.org/10.4236/oalib.1106792

Received: September 5, 2020

Accepted: January 29, 2021

Published: February 1, 2021

Copyright $\odot 2021$ by author(s) and Open Access Library Inc.

This work is licensed under the Creative Commons Attribution International License (CC BY 4.0).

http://creativecommons.org/licenses/by/4.0/

\begin{abstract}
With the rise of COVID-19 cases in many parts of the world, questions around how terrorists could incubate and hibernate their activities within the current global pandemic are becoming more pertinent. The underlying assumption that terrorists lack urgency to permeate the deadliness of COVID-19, cannot only have serious security and policy consequences, but also disengages the very affected communities from taking a leading position in the fight against terrorism. This paper argues that it is the critical investigation and interrogation of the nexus between terrorism and COVID-19 that prevents the creation of a dangerous gap in security processes, therefore rendering the community role in the fight against terrorism even more effective.
\end{abstract}

\section{Subject Areas \\ Sociology}

\section{Keywords}

Navigating, Terrorism, COVID-19, United Nations, Communities

\section{Introduction}

For several decades, numerous communities around the world have continued to lead a terrorism and violent capped life. Today, the same world is grappling with even more deadly coronavirus disease commonly known as COVID-19. In attempting to navigate my perspectives on the two foes of humanity, I make reference to the works of Colin P. Clarke who attempted to project how the year 2020 would look like in terms of terrorist activities. Other points of departure in my discussion include the United Nations (UN) report on the Islamic State in Iraq and the Levant (ISIL). In addition, the travel advisory on European conti- 
nent by Islamic State in Iraq and Syria (ISIS) leadership had to a certain extent sounded some farewells to terrorism than conflict of common understanding. Perhaps, the imminent extinction of terrorism was further seen as possible in the unique call by the United Nations Secretary General for global ceasefire on conflict in order to dedicate the fight on COVID-19. However, as will be argued in this perspective, terrorism extinction is far from being achieved. Instead, the hope for its elimination by COVID-19 has been reduced by the drawing-in or repositioning of terrorist attacks in various regions of the world. This is so because COVID-19 pandemic is far from dismantling terrorist objectives or posing any serious health security to destroy their identities.

\section{Context}

Worth factoring in this perspective, is Clarke's works on "Trends in Terrorism: What is On the Horizon in 2020", Clarke (2020) [1]. This work projected that, geo-political realignments, emerging technologies, and demographic shifts were areas that would all contribute to different manifestations of ideologically and politically motivated violence in the year 2020 . He argued that, while terrorist groups such as the ISIS would continue losing their physical caliphate through anti-terrorist interventions, there was a flipside of this chart. The argument was that the group's loss of the physical caliphate would also make ISIS network more difficult to target since it was likely to be more decentralized. Also, Clarke indicated that these challenges were likely be compounded by the threat posed by the returning foreign fighters (RFFs) to their countries of origin. It becomes a huge security problem especially when these foreign fighters include unaccounted for militants that might infiltrate conflict zones and serve as force multipliers for jihadist groups fighting civil wars or insurgencies in weak and failed states. For example, the Al-Qaeda and its affiliated organizations were viewed as likely to consolidate their ground in conflicts in Syria and Yemen, including parts of the Sahel and the Horn of Africa. But, programmes meant to redress the security dynamics have also been marred with research and operational gaps. This manifests largely with minimal or complete absence of women's participation in such programmes. Yet, women have constituted a reasonable proportion of demographics that participate as terrorist perpetrators as well as largely being victims of such acts. For example, Turkington Rabecca and Christien Agathe (2018: 3) [2], argued that there has been little consistency given to gender dynamics and gender specificity in de-radicalization programmes.

However, wisdom in Clarke's work implies that terrorist groups such as the Al-Qaeda and its affiliates throughout the world would retain the ability to launch spectacular attacks, as evidenced by Al-Shabaab in Somalia and Boko Haram in Nigeria killings of several people. The UN report (2020) [3], amplified Clarke's work with a security synopsis that, ISIL was reasserting itself both in the Syrian Arab Republic and Iraq. This report by the global body reflects a lot of variables at play. For example, it denotes an acceleration of ISIL's reconstitution following the fall of its geographical "caliphate" in the recent past years. Beyond 
the ISIL and their core conflict zones, extra attention should be paid to the existential threats from Al-Qaeda and ISIL affiliates globally. Classic examples of AI-Qaeda's continued existence can be tracked in Afghanistan and its immediate neighborhood. These groups are also in other parts of South-East Asia, East and West Africa, ravaging the stability of fragile Member States in the regions. In East Africa, Al-Qaeda affiliate Al-Shabaab has maintained a steady pace of attacks on security forces and foreign targets. This means terrorists have continued to occupy public spaces with violence while adapting and exploiting the vulnerability of soft targets such as shoppers, diners, tourists, worshippers, etc. To protect these targets, there is need for better understanding of the threats, enhanced collaborated partnerships and capacity building across various levels of intervention.

To augment the threat projections, it is better also to borrow from the New York Post of 15 March 2020 [4], which carried a story dubbed "ISIS tells its terrorists not to travel to Europe for jihad because of coronavirus". This advisory also urged any sick jihadists already in Europe to stay there according to a "sharia" directive as prescribed in the group's al-Naba newsletter. It also appealed to those outside Europe not to enter the land of the epidemic, thus continental Europe. Contrary to the advisory, the report on ISIL by the UN Under-Secretary General and head of UN Office of Counter-Terrorism, Mr. Vladimir Voronkov, reinforced the assertion that the threat from violent extremists and terrorists had not diminished by COVID-19. In fact, it indicated that ISIL had remained at the centre of the international terrorism threat, especially in the group's reach such as Africa, Europe and Asia (UN News, 7 February 2020) [5]. The Under Secretary General's report did not only reassert the threat existence but illuminate the consolidation of the UN role in the fight against terrorism. Before 9/11 terrorist attacks in the United States of America, there was literally less research done on terrorism and violent extremism. Even the role of the United Nations in combating terrorism was less visible. This is because, prior to the emergence of AI-Qaeda and other violent non-state armed groups at the end of the twentieth century, terrorism was perceived as a domestic matter, and one that states were reluctant to internationalize (Fink 2012:1) [6]. While the international community is now fully aware of the existential threat within COVID-19, which is coming from violent extremist groups, there is one question to takeout of this perspective; can the pandemic destroy terrorist activities? The simple answer to this question, is that COVID-19 is far from terminating terrorism due to communication technology and other areas of vulnerability being exploited by terrorists.

\section{Further Modelling of the Perspectives}

The modeling of withdrawal by ISIS from terror activities in the face of the persistent COVID-19, is not based on concrete evidence from the ideological point of view that the disease can actually deter or dilute terrorist activities. The situational equation is that deterring terrorist activities as illustrated by 
ISIS advisory on Europe is minimally possible but the mitosis of group's activities into COVID-19 diseased international demographic communities remained imminent. For example, this imminence cuts across both peaceful and fragile countries, as argued by Clarke (2020) [1] that terrorism can potentially infiltrate conflict zones. Clarke's work validated the works of other researchers such as Sageman (2004:137) [7] who conceived terrorist group as a social movement of individuals and cells connected to each other through complex webs of direct or mediated exchanges. The knowledge and networks developed by terrorists is brought together in a systematic way which gives them strong footing in their ideological agendas.

Apparently, these are the social movements and cells that transform domestic terrorism into transnational in nature. For example, internal security dynamics and religious fundamentalists, combined together produce security undercurrents in which it is hard to defend the majority of their soft targets. This could happen with potency despite the on-going COVID-19 pandemic, as long as the victims, perpetrators and the larger audience find themselves within a defined venue of attack. For example, religious sites which are symbols of social solidarity are grayed for attacks. This means that terrorist groups could continue to brace themselves with COVID-19 despite the disease manifesting itself in supra-terrorist fashion of the twenty first century. Simply and without measure of exaggeration, the "epidemiology of traditional terrorism" has continued to exist within the armpit of COVID-19 ferocity. What this means is that, the initial withdrawal of terrorist activities in the face of COVID-19 was merely arm pitted in the disease without destroying it. The role of communities in both withdrawal and in-drawal remains critical to the existence or elimination of terrorism. This paper, therefore, does not judge how individual anti-terror projects involve communities nor how community resilience is built and sustained. Rather, the article takes issue with the importance of community resilience in the fight against terrorism.

For example, in a Presidential Statement that called for greater efforts to help Africa fight terrorism of 15 March 2020 [8], the UN Security Council acknowledged terrorism and violent extremism as posing serious threats to Africa. Also, the document S/PRST/2020/5 issued in March 2020 by China in her capacity as the President of the UN Security Council implored for scaled-up and effective implementation of Resolutions that fight the Islamic State in Iraq and the Levant (ISIL), Islamic State in Iraq and Syria (ISIS), AI-Qaeda and their affiliates. In fact, it advocated for measures inculcated in a holistic package that fight the vice in general and community involvement qualifies this advocacy. These statements signaled the negativities gravitating in violent terrorism. The end result is the aggressive cyclone of the deadliest security effects across the world communities. The emerging COVID-19 versus terrorist oriented security landscape, is what the world is facing as the existing characteristics of terrorism. As indicated in his opening remarks during the counter-terrorism week (6-10 July 2020), the UN Secretary General Antonio Guterres noted that, COVID-19 has severely dis- 
rupted health systems, economies and local communities thereby creating fragility in many aspects of human life [9]. The United Nations Chief also acknowledged the continued presence of ISIL, AI-Qaeda and their affiliates that prey on social divisions, governance failures and local conflicts to advance their objectives.

As such, the issues of physical security and public health challenges have been given equal attention and weight on the world leaders' agenda for international tranquility and social justice. For example, on 23 March 2020, Daniel Dickinson of United Nations (UN News) [10] reported that the UN Secretary General, Antonio Guterres called for global ceasefire aimed at putting armed conflict on lockdown in order to focus collectively on the true fight of COVID-19 pandemic. The UN Chief pointed out that, COVID-19 does not care about nationality or ethnicity, or other differences between people, and "attacks all, relentlessly", including wartime. While the Secretary General's timely call was done from the broader field of peace and security mandate of the UN, it also carried with it unique emphasis that, the disease had popularized itself outside the traditional health spheres, therefore affecting everyone and everywhere. It reflected that COVID-19 had gained traction in every sphere of humanity, and that fighters or terrorists in all parts of the world were equally vulnerable. It therefore reflected the appropriateness of all efforts in anti-terror and health spheres to submit to this new substantive reality. This is occurring in times when ISIL continues to reassert itself in Iraq and Syria, a situation which is dynamically interacting with challenges to do with the presence of foreign fighters in their traditional regions or engaging in local conflicts elsewhere.

This explains why holistic approach in the fight against terrorism is predominantly in three stages. The primary level focuses on prevention, particularly in community settings, and the secondary level concentrates on those at risk of becoming radicalized. Tertiary level interventions provide services for those who have already engaged in violent extremism, principally in the form of de-radicalization, disengagement and reintegration (DDR) programmes (Richardson et al. 2017:31) [11]. By any standard of analysis, as deadly as terrorism is, it has ascribed as an element of social, economic and political infertility, that incubates itself within the current global pandemic environment. The continued rebranding of groups that comprise scattered individual terrorists such as Al-Shabaab in Somalia, provides evidence that the withdrawal created in the infant stages of COVID-19 was very temporal. The proliferation of attacks across the world, is a reflection of challenges to sustain our civilization. Also, it could mean the incompablility of ideologies in the peace discourse. In fact, calls by ISIS leadership on its members to avoid Europe could provide fertility for the mitosis of group activities in current regions of hibernation. Individual terrorists may continue operating under the thread-like satellite structure of the main terrorist groups, thereby infiltrating the "diseased" anti-terror mechanisms, as well as the locked-down demographic formations and applied response mechanisms to COVID-19. 
In this case, it is inevitable to inference the isolated terror cases upon the entire regime of terrorism amidst the prevailing health circumstances. These situations exist in groups' desired tactics of attaining ideological goals by all means and at all cost. The evils of COVID-19, which is a ravenous flu never seen before by largest proportion of the world populations, have therefore not insulated terrorism from happening.

As such, the mix of COVID-19 and terrorism validates the argument that solutions still depend on the level of community involvement. As COVID-19 continues to flip side the world in the trajectories of humanity, it is surely not a footnote but a memorable epoch in global history, which is sweeping through already terrorist prone communities. In fact, these dynamic tradeoffs between physical security and health, give fresh content to the curation of new security space. Any terror attack in any one location, is an attack in too many. Therefore, the syndrome of "remoteness" which is devoid of integrated partnerships, undermines the importance of this understanding.

This means that putting one risk on the side ring of the other, is breaking loose the gravity of the existential threats currently facing the world. The narrative of "not so much resources, not so much effort" would only depict global publicity contestation as opposed to an effective fight against COVID-19 and other "come along" security threats. As a new form of invisible terrorism in its collective sense, COVID-19 is squarely and descriptively a razor deadly disease, which has managed to bourgeon itself on the apex of global public health index. However, its viciousness is never enough venom to the existing "thread-like" terrorist arrangements which exploit COVID-19 presence within the affected populations. The implications are that any interregnum action against the two problems should be prevented as letting the process loose opens up further damage to the already desperate situation. For example, the African continent has in the recent past witnessed a surge in the number of terrorist attacks particularly in countries such as Mali, Burkina Faso and Niger. In fact, the Country Representative of the Catholic Relief Services in Mali, Moussa Dominique Bangre observed that COVID-19 was potentially weakening Mali's capacity to respond to jihadist attacks (Crux 2020) [12]. In this case, the involvement of the affected communities and other interest groups in the fight against these threats remains pivotal to the insulation of the very communities for sustainable security. This is crucial to the building of community resilience against peace evading terrorist cells or lone attackers, that have changed people's way of life around the world. While security agencies hold the primary mandate to protect people, communities are vital in intelligence gathering, local knowledge and legitimacy to the policy formulation and response.

In other words, continued consolidation of emerging collective charisma against terrorism and COVID-19 provides a "good platform" to the global community reeling from security and health uncertainties. It would accord communities the required deep breath while calming the minds of the entire world on the existing 
threats to their survival. The plateauing of the COVID-19 infection rates and the prevention in the surge of terrorist activities, should be central in the curation and management of new security atmosphere. Any uncoordinated international efforts, would render self-punching holes in the response, and might worsen the polarity of the situation. With the wide-scale lockdown around the world, further strategies that require the balance between the unique risks and the available capacities are still needed. It accords the world an opportunity to contain negative effects of COVID-19 from becoming uncontrollable. Additionally, it permits the wrapping and control of all security threats using the overarching role of communities in the fight against terrorism. To achieve it, we need reflective praxis where quality thinking should not be replaced by thoughtless actions. Of course, specifics of the response should be drawn from data-based arguments and context assessments. This is important because, identifying terrorists within soft targets settings is a very complex process because terrorists do not need a lot of resources for infiltration of a mingling population. Therefore, this article is not meant to stoke rumors or trigger panic on existential terrorism threats within COVID-19 life span.

The article is meant to reflect on the pre-COVID-19 security projections and the current reality. Also, to remind ourselves that, so far nothing tangibly shows that the projected threats have been destroyed by the pandemic to render non-return of terrorists on the security stage.

The Armed Conflict Location and Event Data Project (ACLED) notes that attacks by groups located in Sub-Saharan Africa and affiliated to Al-Qaida, including the Islamic State in Iraq and the Levant (ISIL, also known as Da'esh) increased by 37 per cent between mid-March 2020 and mid-April 2020 (UN Security Council 2020: 3) [13]. Also, the Counter-Terrorism Committee Executive Directorate (CTED) has identified short-term opportunities such as the COVID-19 related lockdowns, furthered terror narratives, and alternative terrorist linked service provisions etc, as avenues to advance terrorism (ibid:1-2) [13]. These circumstances leave the world with few options but acceptance of the new reality and the need to craft different approaches in which community role is enhanced. This is what this debate is all about. So far, as with-drawals and in-drawals of terror cells oscillate in the strides of human survival, the article appreciates what is being mobilized to prevent the world from descending into "hard to retrieve" health and security situations.

This is important because COVID-19 has taken the world off guard, or simply exposed the unpreparedness of the world for such a pandemic. Its velocity has to some measurable extent, outweighed the capacity of the health institutions, both national and international. These health care systems include those that are ordinarily and fundamentally sustained by the support of the developed countries. To demonstrate the case in point, some of the developed countries that constitute the beacons of strong health systems and effective security surveillance mechanisms, have fallen prey to both the pandemic and security dilemmas. In this 
case, the implication is that, the institutionalization of the responses through huge financial resource allocation alone, does not constitute "one size fits all" solution to the current problems. In other words, it does not easily shield the world against the disease, nor does it guarantee a clear pathway to immediate defeat of terrorism.

In the same logic, this does not mean that substantive affirmations from international financial institutions should be put aside in mobilizing concerted efforts. It simply means that, while COVID-19 can be conceived as possible carrier of terrorism in the current times of uncertainty, this navigational analysis finds solutions to these self-reciprocating human calamities by engaging and enhancing community resilience. The use of community elasticity to support institutions, is the common denominator in the search for sustainable solutions as they refract towards reinforcing community capacities. For example, public health experts have accelerated their messaging to the world in the redefinition of "proximity" or "social distancing" as a widely known effective response strategy. In so doing, social distancing is indirectly dispersing crowds that are ordinarily targeted by terrorists. Without any measure of overstatements, the invisibility of these targets through COVID-19 response can also become conducive demographics to wage terror attacks in the new security space. So, depending on how response strategies to COVID-19 and anti-terrorism are developed, they can exacerbate radicalization if framed without critical interrogations of the interconnection between the pandemic and security dynamics. In both situations, the involvement of communities as first responders to physical and emotional effects, including offering early warning is crucial to the success of any response.

\section{Limitations of This Research}

The paper has considerably attempted to draw itself away from the detailed discussion on the COVID-19 and terrorism nexus. All it has brought to the research forum is to highlight the characteristics of this nexus and how it does not guarantee terrorism free world. For example, as alluded above, COVID-19 is being responded to through social distancing (physical and face masks) among other approaches, but this paper does not discuss in detail how the captive populations can or cannot provide a conducive environment for the mitosis of terror activities. However, what it has pointed out is the possibility created and its propensity to be used as a drive to fight terrorism. In some cases, populations can act as an incubation cell for terrorism. On the same point of sensitivity, this paper is still limited on the impact of media refocus to COVID-19, away from the propagation of narratives that relate to radicalization and violent extremism. Can the re-focus of the media from terrorist groups to COVID-19, affect also the allocation of resources to fight the scourge of terrorism or may create alternative service providers with accelerated anti-State violence?

These questions are critical in laying the ground for further research on the new security landscape, created by the seemingly mutually reinforcing threats of 
COVID-19 and terrorism. As indicated in the introductory stages of this paper, numerous communities around the world have continued to lead a terrorism-and violent capped life. However, challenges of countering terrorism are not new, and indeed have a long history. According to the University Module Series on Counter Terrorism published by the United Nations Office on Drugs and Crime (UNODC) in 2018 [14], the term "terrorism" was initially coined to describe the Reign of Terror, the period of the French Revolution from 5 September 1793 to 27 July 1794, during which the Revolutionary Government directed violence and harsh measures against citizens suspected of being enemies of the Revolution. In turn, this was met with popular resistance to Napoleon's invasion of the Spanish Peninsula led to a new form of "guerrilla" tactics, which derives from the Spanish word guerra, meaning "little war" (Friedlander, 1976: 52 in UNODC 2018) [14]. As a weapon of politics and warfare, the use of terrorism has continued to wreck humanity in many aspects, therefore challenging the world researchers in political science, peace and security field to accelerate their efforts.

\section{Conclusion}

In conclusion, the article has discussed the spread of COVID-19 whose outbreak gave a very limited push-back to terrorist activities. As noted above, this withdrawal of some terrorists groups from certain regions was temporal, considering numerous statements from world leaders and other commentaries on the presence of security threats by ISIS, ISIL, Al-Qaeda etc. In the quest to respond to both COVID-19 and terrorism, the world leaders have taken to acknowledge the mitosis of terrorist activities with varying degrees of consequences. To mitigate the effects of both the pandemic and terrorism, community mobilization, participation and support has been pointed out as the antidote to the existing problems. As noted around the world today, social distancing has become a COVID-19 fighting household tool. Of course, it is being applied according to context-specific assessments and applications of individual State's health guidelines. In this case, both COVID-19 and terrorism are being addressed by tapping resilience from communities themselves. The communalization of the responses depicts the critical role communities play in seeking solutions to a wide-range of global problems. This means that the loyalty of communities to their own health and security matters, and more importantly, their fidelity to their nation-States in times of crisis can be validated by approaches that rationalize their collective charisma. Thus, the concept of fighting the problems from below remains crucial in defeating both COVID-19 and terrorism. To this end, institutionalized financial and technical support from the top, only consolidates and sustains the bottom-up approach to fight the current two foes of humanity.

\section{Conflicts of Interest}

The author declares no conflicts of interest regarding the publication of this 
paper.

\section{References}

[1] Clarke, C.P. (2020) Trends in Terrorism: What's on the Horizon in 2020. Foreign Policy Research Institute.

[2] Rebecca, T. and Agathe, C. (2018) Women, De-Radicalization and Rehabilitation: Lessons from an Expert Workshop. Georgetown Institute for Women, Peace and Security, Policy Brief.

[3] (2020) UN Security Council Report. https://undocs.org/pdf?symbol=en/S/2020/53

[4] (2020) New York Post.

[5] UN New. https://news.un.org/en/story/2020/02/1056912

[6] Naureen, F.C. (2012) Meeting the Challenge: A Guide to United Nations Counterterrorism Activities. International Peace Institute.

[7] Sageman, M. (2004) Understanding Terror Networks. University of Pennsylvania Press, Philadelphia, PA. https://doi.org/10.9783/9780812206791

[8] (2020) UN Security Council Presidential Statement Calling for Greater Efforts to Help Africa to Fight Terrorism. https://www.un.org/press/en/2020/sc14140.doc.htm

[9] (2020) UN Press Release on Secretary General's Statements and Messages. https://www.un.org/press/en/2020/sgsm20161.doc.htm

[10] UN News. https://news.un.org/en/story/2020/03/1059972

[11] Cara, R., Paul, C.A. and Katherine, B.M. (2017) The Role of Sport in De-Radicalization and Crime Diversion. Journal for De-Radicalization, 13, 29-48.

[12] Crux (2020) Catholic Experts, UN Warn Coronavirus May Exacerbate Terrorism in Africa, 14 May 2020.

https://cruxnow.com/church-in-africa/2020/05/catholic-experts-un-warn-coronavir us-may-exacerbate-terrorism-in-africa/

[13] UN Security Council (CTED) (2020) The Impact of COVID-19 on Terrorism, Counter-Terrorism and Countering Violent Extremism.

[14] UNODC (2018) University Module Series. 